\title{
Post-mortem Change of Three-dimensional Structure of Collagen Fibrillar Network in Fish Muscle Pericellular Connective Tissues Corresponding to Post-mortem Tenderization
}

\author{
Masashi Ando, Yusuke Yoshimoto, Kyoko Inabu, Takayuki Nakagawa, and Yasuo Makinodan \\ Department of Fisheries, Faculty of Agriculture, Kinki University, Nakamachi, Nara 631, Japan \\ (Received September 2, 1994)
}

\begin{abstract}
The three-dimensional structure of a collagen fibrillar network was examined by using a cell-maceration/SEM method combined with measuring the breaking strength of rainbow trout, yellowtail, and tiger puffer muscles. Rainbow trout and yellowtail muscles were tenderized during storage, but tiger puffer muscle showed no tenderization even after $72 \mathrm{~h}$ storage. According to histological observations, the thickness of pericellular connective tissue in rainbow trout and yellowtail muscles became thinner, and the density of their collagenous fibrils decreased during $24 \mathrm{~h}$ storage. On the other hand, no structural change was observed during $72 \mathrm{~h}$ storage in tiger puffer muscle. These results showed that the structural change in the collagen fibrillar network corresponded to the post-mortem tenderization. This result agreed well with previous light microscope and transmission electron microscope observations.
\end{abstract} muscle

Key words: scanning electron microscope, collagen, post-mortem change, tenderization, fish

Firmness is a very important factor for evaluating the quality of raw fish meat. It is generally accepted that fish muscles are tenderized during chilled storage, and many studies have been performed to resolve the cause of postmortem tenderization of fish muscles. ${ }^{1-12)}$

Ando et al. ${ }^{13-15)}$ clarified that post-mortem tenderization of fish muscle was due to a weakening of the pericellular connective tissue of muscle and that the weakening was caused by degradation of the collagen fibrils from observations by a light microscope (LM) and a transmission electron microscope (TEM). On the other hand, observation by a scanning electron microscope (SEM) is much more useful than by a LM and/or a TEM for a study on the three-dimensional structure of muscle. Recently, several studies have been reported on the observation of the threedimensional structure of connective tissue of several organs by using a cell-maceration/SEM method. ${ }^{16-24)}$ Additionally, Ando et al. ${ }^{25)}$ and Itoh et al. ${ }^{26)}$ reported the close relationship between the firmness of muscles and the threedimensional structure of pericellular connective tissue by using the cell-maceration/SEM method.

The purpose of the present study is to observe the structural change in the pericellular collagen fibrillar network of fish muscles during chilled storage, and to discuss the relationship between the structure of pericellular connective tissue and post-mortem tenderization.

\section{Materials and Methods}

\section{Samples}

Rainbow trout Oncorhynchus mykiss (140-160 g, 19-21 $\mathrm{cm})$, yellowtail Seriola quinqueradiata $(2.4-2.6 \mathrm{~kg}, 50-52$ $\mathrm{cm})$, and tiger puffer Takifugu rubripes (690-720 g, 30-32 $\mathrm{cm}$ ), were obtained alive from a local market. After decapitation, the fish were filleted, and each fillet was packed in a polyethylene bag and stored at $5^{\circ} \mathrm{C}$.

\section{Breaking Strength}

The breaking strength of muscle was measured by the method as reported previously. ${ }^{14)}$

\section{Cell-maceration/SEM Method}

The cell-maceration/SEM method ${ }^{24)}$ was used to observe the three-dimensional structure of the collagen fibrillar network of muscle with a slight modification. The dorsal muscle was cut into $3 \mathrm{~mm}$ cubes and fixed in Karnovsky fixative. After fixation, samples were immersed in $10 \%$ $\mathrm{NaOH}$ solution for 3-5 days at room temperature. After rinsing with $1 \% \mathrm{NaCl}$ for $1 \mathrm{~h}$, conductive staining ${ }^{27)}$ was carried out. The samples were dehydrated in ethanol series, frozen in liquid nitrogen, and fractured with a cooled sharp blade. The fractured samples were substituted by 2-methyl-2-propanol, freeze dried, and observed by using a SEM $(5400 / \mathrm{LV}$, JEOL, Japan) with an accelerating voltage of $10 \mathrm{kV}$.

\section{Results}

\section{Breaking Strength}

Breaking strength values decreased during $24 \mathrm{~h}$ storage in rainbow trout and yellowtail muscles, but not in tiger puffer muscle (Table 1) as previously reported..$^{9-15}$

Figures 1-3 show the three-dimensional structure of the

Table 1. Breaking strength values of fish muscles during storage

(g)

\begin{tabular}{lccc}
\hline \hline & \multicolumn{3}{c}{ storage period $(\mathrm{h})$} \\
\cline { 2 - 4 } & 0 & 24 & 72 \\
\hline Rainbow trout & $108 \pm 19$ & $61 \pm 12$ & $49 \pm 7$ \\
Yellowtail & $135 \pm 25$ & $62 \pm 12$ & $60 \pm 8$ \\
Tiger puffer & $182 \pm 39$ & $220 \pm 35$ & $175 \pm 20$ \\
\hline
\end{tabular}

Each value is expressed as the mean of 5-10 determinations \pm S.D. 

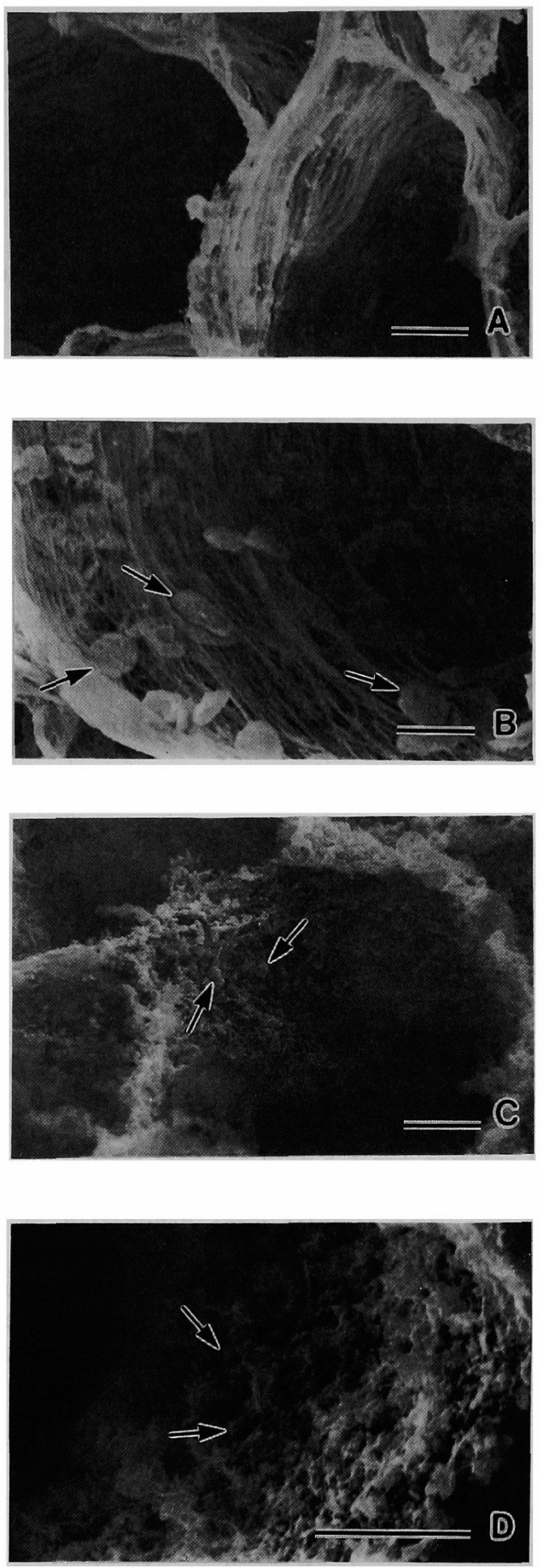

Fig. 1. Pericellular connective tissue of rainbow trout muscle.

$\mathrm{A}$ and $\mathrm{B}$, fresh; C, $24 \mathrm{~h}$; and D, $72 \mathrm{~h}$ storage muscles. In the fresh muscle (A and B), collagenous fibrils are observed, and on the fibrils, phagocyte-like cells exist (arrows). After storage (C and D), pericellular connective tissues are broken, and there are many particles which are about 1 micron in diameter (arrows). Bar $=10$ microns.

collagen fibrillar network obtained by the cell-maceration/SEM method. In this study, $1 \% \mathrm{NaCl}$ was used for washing samples instead of distilled water. This was because the samples expanded and degraded in distilled water during preparation except for tiger puffer muscle (data not shown). The degradation of samples was due to
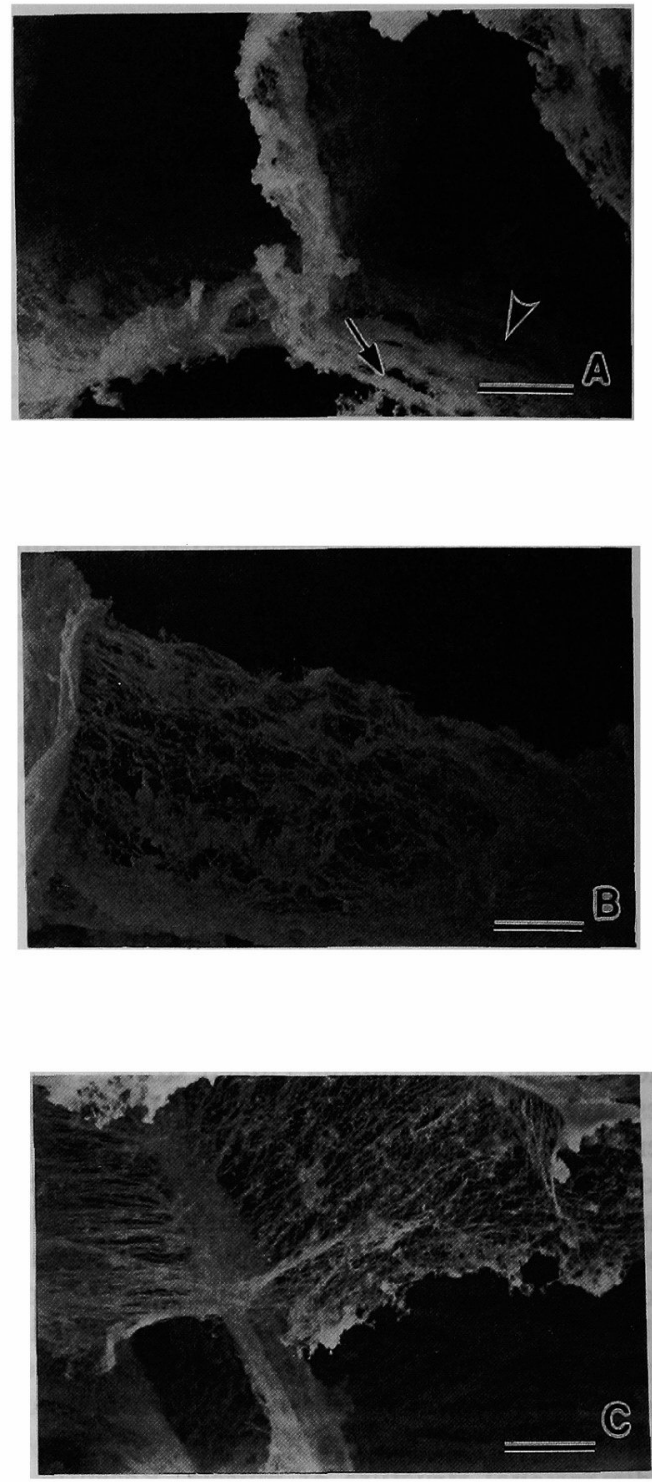

Fig. 2. Pericellular connective tissue of yellowtail muscle.

A, fresh; B, $24 \mathrm{~h}$; and C, $72 \mathrm{~h}$ storage muscles. Thick (arrow) and thin (arrowhead) collagenous fibrils are observed (A). In the stored muscle (B and $\mathrm{C}$ ), the connective tissue becomes thinner and thin fibrils are clearly observed. Bar $=10$ microns.

a difference of osmotic pressure between $10 \% \mathrm{NaOH}$ and distilled water. The expansion or degradation did not occur in the preparation by $1 \% \mathrm{NaCl}$.

In rainbow trout muscle (Fig. 1A), collagenous fibrils were observed and were arranged parallel to each other. There were many particles (5-10 microns in diameter) on the surface of the pericellular connective tissue (Fig. 1B, arrows). These were assumed to be phagocytes and/or fibroblasts which existed in the connective tissue according to their shape and size. ${ }^{28,29)}$ The pericellular connective tissue was thinner than fresh muscle after 24 and $72 \mathrm{~h}$ storage (Fig. 1C and D). In a broken portion of the pericellular connective tissue, particles of 1 micron in diameter were observed (arrows). These particles are thought to be the degradation products of pericellular connective tissue because the particles could not be seen in the fresh muscle (Fig. 1A). 

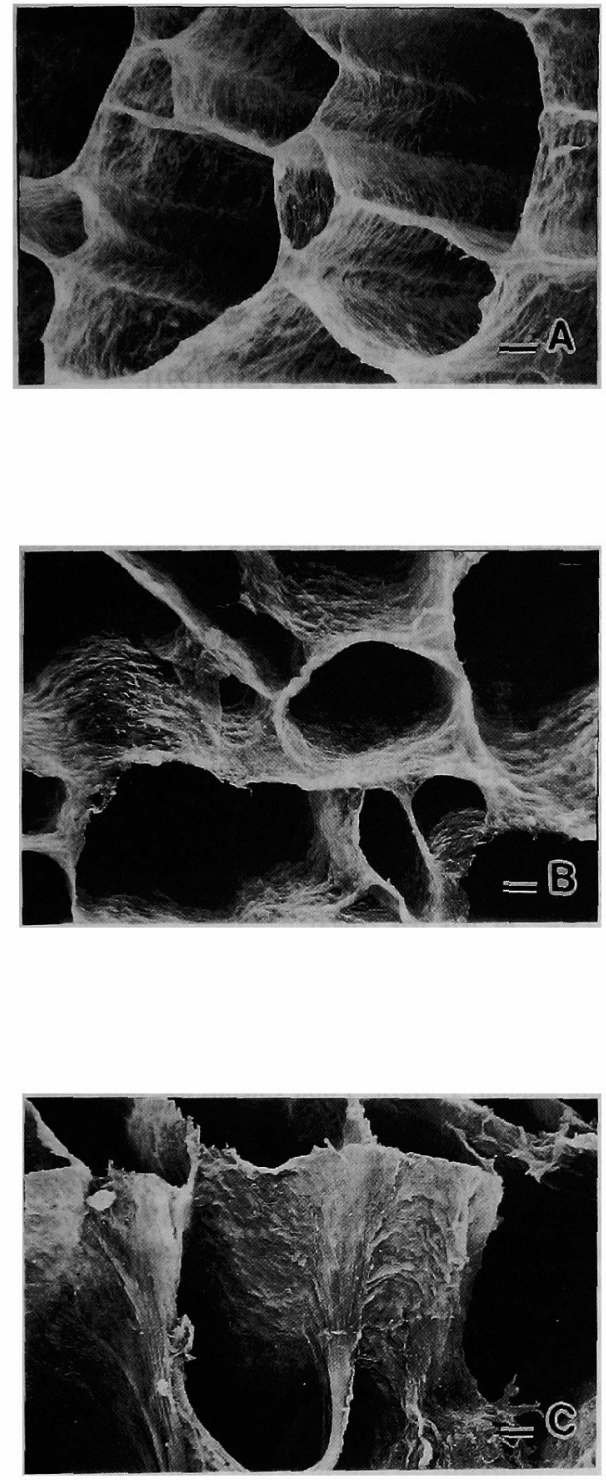

Fig. 3. Pericellular connective tissue of tiger puffer muscle.

A, fresh; B, $24 \mathrm{~h}$; and C, $72 \mathrm{~h}$ storage muscle. No structural change is observed in the pericellular connective tissue even after 72 h storage. Bar $=10$ microns.

In the collagen fibrillar network of yellowtail muscle (Fig. 2A), thick (arrow) or thin (arrowhead) collagenous fibrils were observed. After 24 and $72 \mathrm{~h}$ storage (Fig. 2B and $\mathrm{C})$, fewer thick collagenous fibrils were observed than in the fresh muscle. The pericellular connective tissue became thinner and thin collagenous fibrils were clearly observed.

In case of tiger puffer muscle (Fig. 3A), the pericellular connective tissue appeared to have a uniform membranous structure, and the collagenous fibrils which constructed the pericellular connective tissue were observed at a higher density. In the 24 and $72 \mathrm{~h}$ storage muscles (Fig. 3B and C), degradation of the collagen fibrillar network was not observed, in contrast to rainbow trout and yellowtail. This corresponds to the stability of the mechanical strength of the pericellular connective tissue during storage as previously reported. ${ }^{15)}$

\section{Discussion}

This study clarified the structural change in the collagenous fibrillar network during post-mortem tenderization.

As to the post-mortem change of pericellular connective tissue structure, LM and TEM observations have been performed, ${ }^{13-15)}$ but structural changes were not observed three-dimensionally. The present method enables widerange observations of the three-dimensional structure of the pericellular connective tissue of fish muscle.

In rainbow trout and yellowtail muscles, the pericellular connective tissue seemed to be thinner during storage. This is because the constituents of the pericellular connective tissue became soluble and were eluted by the sample preparation. Montero and Borderias, ${ }^{30}$ and Montero and Mackie $^{31)}$ have reported that intramuscular collagen increases in solubility during storage. In addition, Sato et $a l .{ }^{12)}$ showed that the solubility of type $\mathrm{V}$ collagen increases corresponding to the post-mortem tenderization of rainbow trout muscle. These changes in collagen solubility are related to the structural changes in the pericellular connective tissues in yellowtail and rainbow trout muscles in the present study. In the case of tiger puffer muscle, neither post-mortem tenderization nor disintegration of the collagen fibrillar network was observed (Fig. 3). This stability of the collagen fibrillar network retains the mechanical strength of the pericellular connective tissue during storage. ${ }^{15)}$ It is not clear why the connective tissue of tiger puffer muscle is stable. However, the pericellular collagen of tiger puffer may have some differences in content and/ or characteristics such as sensitivity to proteases compared to other fish species. It is thus necessary to compare the characteristics of pericellular collagen between tiger puffer and other fishes.

\section{References}

1) T. Tokiwa and H. Matsumiya: Fragmentation of fish myofibril. Effect of storage condition and muscle cathepsin. Nippon Suisan Gakkaishi, 35, 1099-1109 (1969).

2) K. Hatae, S. Tamari, K. Miyanaga, and J. J. Matsumoto: Species difference and changes in the physical properties of fish muscle as freshness decreases. Nippon Suisan Gakkaishi, 51, 1155-1161 (1985).

3) N. Seki and B. Tsuchiya: Extensive changes during storage in carp myofibrillar proteins in relation to fragmentation. Nippon Suisan Gakkaishi, 57, 927-933 (1991).

4) K. Tachibana, T. Doi, M. Tsuchimoto, T. Misima, M. Ogura, K. Matsukiyo, and M. Yasuda: The effect of swimming exercise in flesh texture of cultured red sea bream. Nippon Suisan Gakkaishi, 54, 677-681 (1988).

5) N. Seki, and T. Watanabe: Connectin content and its post-mortem changes in fish muscle. J. Biochem., 95, 1161-1167 (1984).

6) L. Busconi, E. J. E. Folco, and B. C. Martone: Fish muscle cytoskeletal network: Its spatial organization and its degradation by an endogenous serine proteinase. Arch. Biochem. Biophys., 268, 203-208 (1989).

7) H. Toyohara and Y. Shimizu: Relation of the rigor mortis of fish body and the texture of the muscle. Nippon Suisan Gakkaishi, 54, 1795-1798 (1988).

8) K. Tachibana, T. Misima, and M. Tsuchimoto: Changes of ultrastructure of cytochemical $\mathrm{Mg}^{2+}$-ATPase activity in ordinary muscle of cultured and wild red sea bream during storage in ice. Nippon 
Suisan Gakkaishi, 59, 721-727 (1993).

9) H. Toyohara, M. Ando, and Y. Shimizu: Appearance of a 38,000dalton component possibly associated with the post-mortem tenderization of rainbow trout muscle. Agric. Biol. Chem., 54, 1575-1576 (1990).

10) M. Ando, H. Toyohara, Y. Shimizu, and M. Sakaguchi: Post-mortem tenderization of fish muscle proceeds independently of resolution of rigor mortis. Nippon Suisan Gakkaishi, 57, 1165-1169 (1991).

11) M. Ando, H. Toyohara, Y. Shimizu, and M. Sakaguchi: Validity of a puncture test for evaluating the change in muscle firmness of fish during ice storage. Nippon Suisan Gakkaishi, 57, 2341 (1991).

12) K. Sato, C. Ohashi, K. Ohtsuki, and M. Kawabata: Type V collagen in trout (Salmo gairdneri) muscle and its solubility change during chilled storage of muscle. J. Agric. Food Chem., 39, 1222-1225 (1991).

13) M. Ando, H. Toyohara, Y. Shimizu, and M. Sakaguchi: Post-mortem tenderization of rainbow trout (Oncorhynchus mykiss) muscle caused by gradual disintegration of the extracellular matrix structure. J. Sci. Food Agric., 55, 589-597 (1991).

14) M. Ando, H. Toyohara, and M. Sakaguchi: Post-mortem tenderization of rainbow trout muscle caused by the disintegration of collagen fibers in the pericellular connective tissue. Nippon Suisan Gakkaishi, 58, 567-570 (1992).

15) M. Ando, H. Toyohara, Y. Shimizu, and M. Sakaguchi: Post-mortem tenderization of fish muscle due to weakening of pericellular connective tissue. Nippon Suisan Gakkaishi, 59, 1073-1076 (1993).

16) O. Ohtani: Three-dimensional organization of the connective tissue fibers of human pancreas: A scanning electron microscopic study of $\mathrm{NaOH}$ treated-tissues. Arch. Histol. Japan., 50, 557-566 (1987).

17) O. Ohtani, T. Ushiki, T. Taguchi, and A. Kikuta: Collagen fibrillar networks as skeletal frameworks: A demonstration by cell-maceration/scanning electron microscope method. Arch. Histol. Cytol., 51, 249-261 (1988).

18) 0 . Ohtani: Three-dimensional organization of the collagen fibrillar framework of the human and rat livers. Arch. Histol. Cytol., 51, 473-488 (1988).

19) O. Ohtani: Corrosion casts in liver and stomach microcirculation, in "Cells and tissues" (ed. by P. M. Motta), New York, 1989, pp. 317-326.

20) O. Ohtani, A. Kikuta, A. Ohtsuka, and T. Murakami: Organiza- tion of the reticular network of rabbit peyer's patches. Anat. Rec., 229, 251-258 (1991).

21) A. Kikuta, O. Ohtani, and T. Murakami: Three-dimensional organization of the collagen framework in the rat adrenal gland. Arch. Histol. Cytol., 54, 133-144 (1991).

22) T. Morita, T. Shimada, H. Kitamura, and M. Nakamura: Demonstration of connective tissue sheaths surrounding working myocardial cells and Purkinje cells of the sheep moderator band. Arch. Histol. Cytol, 54, 539-550 (1991).

23) Y. Komai and T. Ushiki: The three-dimensional organization of the collagen fibrils in the human cornea and sclera. Invest, Ophthalmol. Vis. Sci., 32, 2244-2258 (1991).

24) 0 . Ohtani: The maceration technique in scanning electron microscopy of collagen fiber frameworks: Its application in the study of human livers. Arch. Histol. Cytol., 55, Suppl., 225-232 (1992).

25) M. Ando, H. Toyohara, and M. Sakaguchi: Three-dimensional structure of collagen fibrillar network of pericellular connective tissue in association of firmness of fish muscle. Nippon Suisan Gakkaishi, 58, 1361-1364 (1992).

26) K. Itoh, H. Toyohara, M. Ando, and M. Sakaguchi: Disintegration of the pericellular connective tissue of ayu muscle in the spawring season relevant to softening. Nippon Suisan Gakkaishi, 58, 1553 (1992).

27) T. Murakami: A revised tannin-osmium method for noncoated scanning electron microscope specimens. Arch. Histol., 36, 189193 (1974).

28) P. H. Steiner, S. H. Broderson, and J. Liston: Ultrastructural localization of lysosomes in coho salmon and steelhead trout muscle. $J$. Food Sci., 49, 975-976 (1984).

29) M. Yamashita and S. Konagaya: Immunohistochemical localization of cathepsins B and $L$ in the white muscle of chum salmon (Oncorhynchus keta) in spawing migration: Probable participation of phagocytes rich in cathepsins in extensive muscle softening of the mature salmon. J. Agric. Food Chem., 39, 1402-1405 (1991).

30) P. Montero and J. Borderias: Effect of rigor mortis and aging on collagen in trout (Salmo irideus) muscle. J. Sci. Food Agric., 52, 141-146 (1990).

31) P. Montero and I. M. Mackie: Changes in intramuscular collagen of cod (Gadus morhua) during post-mortem storage in ice. J. Sci. Food Agric., 59, 89-96 (1992). 